Article

\title{
Sustainable Urban Development Calls for Responsibility through Life Cycle Management
}

\author{
Miro Ristimäki * and Seppo Junnila \\ Department of Real Estate, Planning and Geoinformatics, Aalto University School of Engineering, \\ Real Estate Business, Espoo 02150, Finland; E-Mail: seppo.junnila@aalto.fi \\ * Author to whom correspondence should be addressed; E-Mail: miro.ristimaki@aalto.fi; \\ Tel.: +358-40-139-3400.
}

Academic Editor: Gayle C. Avery

Received: 19 August 2015 / Accepted: 9 September 2015 / Published: 11 September 2015

\begin{abstract}
Urban development bestows a great opportunity to increase sustainability in the built environment as cities are responsible for the majority of environmental impacts. However, the urban development process is fragmented and sub-optimization leads to unsustainable life cycle outcomes. The purpose of this study is to examine the urban development process from a life cycle perspective and identify how different actors understand life cycle management. By utilizing an inductive qualitative research design, 38 in-depth thematic interviews were conducted within the Finnish urban development industry including a case study and independent interviews from different phases of the urban development life cycle. The theoretical perspective is a combination of the ecosystem construct and life cycle management. Results show that there is no clear responsible actor for life cycle management in urban development. All actors claim that there is value to be added, mostly in economic, but also environmental and social terms. This study reveals that investors should be the responsible actor in the urban development process. By claiming responsibility and focusing on life cycle leadership we can improve sustainability in urban development, and respond to the urban sustainability challenge, thus improving the quality of life and welfare in our urban society.
\end{abstract}

Keywords: urban development; urban sustainability; life cycle management; sustainability; life cycle assessment; life cycle approach 


\section{Introduction}

Cities and the built environment have significant potential to mitigate global warming. In terms of sustainability, cities generate about $80 \%$ of all greenhouse gas emissions, consume $75 \%$ of energy globally, and $30 \%-40 \%$ of all energy consumption and carbon emissions are caused by the current building stock $[1,2]$. In addition to the sustainability challenge, our cities are growing faster than ever. The trend of global urbanization is increasing. Urban areas comprise $2 \%$ of the terrestrial surface, and future projections imply that by 2050 around $70 \%$ of the global population will live in cities [3]. Consequently, the urban sustainability challenges question the future efficiency and viability of our cities [4], challenging our existing urban development practices and forcing us to modify and develop our approach.

Urban development presents a grand opportunity to enhance sustainability for cities and the built environment. Especially in the commercial and residential sector there is a $30 \%$ reduction potential (relative to the 2020 projected emission baseline), which is seen as the highest mitigation potential overall [3]. By harnessing this potential in the built environment, real estate and construction sector, we are able to promote sustainability by decreasing greenhouse gas emissions and add value to urban development [2,5].

Urban sustainability is defined as the combination of the global sustainability challenge and the trend of urbanization [6]. Urban sustainability is to be understood as a comprehensive ecosystem where different actors interact with each other. Sustainable development is commonly defined as "the simultaneous pursuit of economic prosperity, environmental quality and social equity" [7]. Different actors in the ecosystem are simultaneously aiming at the triple bottom line in order to enhance sustainability. Thus, sustainable value is created only if all three (economic, ecological and social) components are enhanced. A life cycle management perspective is utilized to continuously improve and to enhance sustainability performance along the whole life cycle [8]. This study examines sustainable value creation in urban development through a life cycle management perspective.

Life cycle management is defined by Hunkeler et al. [9] as: "an integrated framework of concepts and techniques to address environmental, economic, technological and social aspects of products, services and organizations". While various complementary definitions from different perspectives exist, Baumann and Tillman's [10] definition of "managerial practices and organizational arrangements that apply life cycle thinking" is an appropriate addition in outlining the perspective for this study.

Cities and urban structures have long life cycles, and therefore it is essential to obtain a long-term perspective in urban planning and development activities. However, it can be argued that public and private organizations still make procurement decisions emphasizing the initial costs and do not apply a life cycle assessment perspective even though there might be significant savings in the long-run by doing so [11]. Furthermore, the urban development process is fragmented; and there are various actors involved that maximize their own business and create sub-optimization, which leads to an unsustainable outcome from a life cycle perspective [12-14]. Thus, the assumption is that no actor takes responsibility for the life cycle outcome and actively drives life cycle management in urban development.

The academic literature presents several examples to unite and integrate activities, i.e., enhancing a life cycle approach within the urban development process from different perspectives. Different life cycle service offerings and integrated solutions have been presented in order to create long-term value 
in the construction industry [15-18]. These integrated solutions can involve design, construction, financing, maintenance and operations where a systems integrator coordinates and manages these activities to optimize the life cycle performance. The perceived benefits are increased quality, improved environmental performance and focus on customer needs. The identified challenges for these integrated solutions was seen as the management of various business models in order to deliver life cycle value [19]. An additional management model proposition, through-life-management, is presented by Koskela [20]. He proposes an analysis framework through initiatives with the purpose of understanding what constitutes through-life-management, thus advancing the life cycle management analogy. In terms of valuation, Lützkendorf and Lorenz claim that property valuation is changing towards life cycle performance based principles where sustainability indicators play a significant role [21]. This claim is supported by Kats who has found that by investing in sustainable design and construction, savings from a life cycle viewpoint considerably exceed upfront costs [22]. Moreover, a strategic method for technical life cycle management for properties is presented in order to manage facilities to better maintain value [23]. These are few examples of life cycle management models. However, none of these studies comprise a comprehensive urban development life cycle scope.

A holistic life cycle approach would result in a more coherent urban development process. By disregarding a life cycle perspective in urban development, potential positive impact on sustainability may be lost. Thus, the life cycle approach does not receive the consideration needed to genuinely enhance sustainable urban development [24].

This study is positioned through a theoretical perspective in order to shape the research and especially to direct the way data is collected and analyzed [25]. The theoretical perspective to shape this research is a combination of the ecosystem construct and life cycle management approach. Such a theoretical perspective has not been utilized previously when examining urban development.

The ecosystem construct was initially pioneered by Moore [26] to describe value creating actions within a network [27]. The ecosystem construct is defined by Thomas and Autio [28] as: "A network of interconnected organizations, organized around a focal firm or a platform and incorporating both production and use side participants". The motivation behind selecting the ecosystem construct is the embracement of use side participants unlike other networks in management literature. In comparison, the urban development entails the process of creating the urban environment (comprising both properties and supporting infrastructure) in collaboration with various actors such as authorities, businesses and use side participants [29]. In this research, investors represent the customer and use side participants through the responsibility of arranging attractive investments within urban development (residential, commercial, retail, etc.). As urban areas and ecosystems have clearly identified resemblances [30-32], the ecosystem construct is applied to examine value creation, delivery and capture within the urban development process from a life cycle perspective.

The ecosystem construct is combined with the life cycle management approach where development towards increased sustainable performance within the value chain is pursued by mitigating sub-optimization between different life cycle stages [8]. Organizations need to move beyond their regular boundaries and increase their communication and co-operation throughout the whole value chain [33]. However, while various actors have the possibility to affect the life cycle outcome, none of them completely control the whole chain [34]. If the life cycle management approach is applied 
successfully, sustainability (triple bottom line) and benefits for the businesses involved can be realized (added value) [8].

The purpose of this study is to examine the urban development process from a life cycle perspective and identify how different actors understand life cycle management. Who is responsible for life cycle outcome and do actors see that there is added value to be created in urban development by attaining a life cycle perspective? Additionally, tools and methods to enhance life cycle management are examined to provide practical suggestions for improvement. Examples of tools and methods are various life cycle sustainability assessment (LCSA) tools such as life cycle costing (LCC), environmental life cycle assessment (LCA) and social life cycle assessment (SLCA) [35,36]. Life cycle sustainability assessment tools have recently been applied in urban development to identify sustainable design and energy system options [37-39]. Through these tools a life cycle perspective in urban development is obtained and informed decisions can be made with a long term sustainable perspective.

Research Questions:

(1) How is life cycle management understood within urban development?

a. Who is responsible for life cycle outcome in urban development?

b. Is there added value generated by improved life cycle management?

c. What kind of tools are needed to enhance life cycle management?

The results of this study reveal that there is no clear actor responsible for life cycle management in the built environment due to conflicts between public and private sector interests, unsuccessful alignment of business models and a lack of clear targets for urban development projects. All actors see that there is added value to be created, mostly in economic terms, but also environmental and social benefits. Moreover, the majority of the actors involved see that the investors and owners should be the responsible entity in the urban development process. Current tools for enhancing life cycle management were seen as inapplicable and in need of development.

This study shows that there is a lack of life cycle responsibility in urban development and possibly a potential demand for a life cycle leadership concept. Evidently, there is value to be created through strengthening life cycle management in terms of sustainability. By focusing on the challenges identified in this study we are able to improve the quality of our built environment and urban sustainability.

This study continues with research design and methods in Section 2. The results are disclosed in Section 3. Discussion in Section 4, including validity and reliability of the research. Conclusions and further research are presented in Section 5.

\section{Research Design and Method}

An inductive logic of qualitative research is utilized in this study [25]: The inductive research process starts with gathering information through open-ended inquiries from participants, after which the data is analyzed to form themes and categories. Thereafter, the researcher identifies and presents patterns, generalizations or theories from the data. To conclude, a conceptual framework of life cycle management in urban development is presented to provide an illustrative overall understanding and to highlight the key findings of the study. The proposed conceptual framework is defined as a network or "a plane" of interlinked concepts that together provide a comprehensive understanding of a phenomenon [40]. 
Similar conceptual frameworks have been used to better understand sustainable development as a multidisciplinary and complex phenomenon [41].

A research design including a case study and a set of independent interviews is applied to describe experiences of the phenomenon life cycle management from the urban development process in Finland. Methods used for data collection are 38 open-ended thematic interviews from a case study (12 interviews) and from different actors within the urban development industry (26 interviews) in order to empirically construct the life cycle value chain of urban development.

\subsection{Empirical Data}

The empirical data set consists of a case study and independent interviews. The independent interviews are from the urban planning phase and operational phase with the purpose of together with the case study constructing a comprehensive urban development life cycle value chain in Finland. A questionnaire to verify assumptions was executed after each interview. In addition, the researcher acted as a participant observer in the case-study for about eight months before conducting the open-ended thematic interviews.

Case study is a form of inquiry through which the researcher attains an in-depth analysis of the case which is bound by time and activity [42]. The aim with the independent interviews is to obtain knowledge from individuals; how different participants in the urban planning and operational phase understand life cycle management as a phenomenon. Both empiric data sets are seen as equal and primary data regarding interpretation and analysis of the study. By constructing this empirical data set the whole urban development process was examined by combining an in-depth case study and extending understanding to both early planning phase and the operational phase by the independent interviews. Thus, an urban development life cycle data set was constructed for this research.

The open-ended thematic interview questions were divided with the help of identified perspectives into five main themes to reflect the research questions (Appendix 2). The purpose of the first theme was to orientate and position the interviewee within the ecosystem by inquiring of their role/position and value creation and capturing mechanisms within urban development. The second theme was examining how they understand life cycle thinking and how life cycle perspective is seen in their business model and in the whole value chain. In addition, life cycle leadership as an idea/concept was examined. Thirdly, the responsibility of life cycle managers in urban development was raised. The fourth theme examined value creation generation through a life cycle management perspective. Fifth, tools and methods to enhance life cycle management was investigated in order to identify constructive practical suggestions to support the life cycle approach. After the interview a questionnaire was answered by the interviewee in order to verify certain assumptions from the interview. The purpose of the questionnaire was to obtain indications in order to validate some of the research questions.

The actors examined in this study were selected by their role and ability to create and capture value within the urban development ecosystem - both production and use side participants. The main actors within the production side are public authority, developer, architect, various consultants and contractors, and the main actors within use side are public authority, tenants, property managers and property investors [43]. 


\subsubsection{Case Study_Urban Development of Kivistö}

Urban development of Kivistö is a part of the city of Vantaa. Vantaa is one of the four cities shaping the Helsinki Metropolitan area in Finland. The urban development of Kivistö comprises a new city part. In this research the case study is limited to the development of the city center which includes approximately 70,000 sqm of commercial, office and public services and 30,000 sqm of residential development, thus representing a comprehensive urban city scope. The actors interviewed for the case study were the city authority (2) (real estate development and zoning), developers (3), contractors (2), consultants (3) (architect, traffic designer, commercial) and retail tenants (2).

\subsubsection{Independent Interviews from the Operational Phase of Urban Development}

The selection of actors for the independent interviews was based on creating a seamless life cycle construct. Actors such as investors, real estate management providers and consultants were chosen as the extension to the case study. Additionally, supplementary city authority viewpoints were added to represent the early phases of urban development. Thus, the actors interviewed from the urban development industry were the city authority (5), consultants (3) (sustainability, project management, and construction management), real estate management providers (3) and property investors with a different product mix (15). In order to attain a strong sampling from the property investor market, who is seen as the client and use side participant in the ecosystem model, the nine largest property investors in Finland were selected and additionally supplemented with different kinds of property investors to represent an overall sampling of the market. The interviewed property investors and property owners represent approximately $63 \%$ of the Finnish investment market 2014 [44].

\subsection{Data Analysis}

The list of interviewees can be seen in Appendix 1, interview questions and verifying questionnaire can be seen in Appendices 2 and 3, and the results of the questionnaire in Appendix 4. The interviews were audio taped and notes were written during the interview. Directly after the interview the content was documented.

The data was analyzed and interpreted separately for the case study and independent interviews. Both data sets were analyzed and coded according to qualitative data analysis stages presented by Creswell [25]. First, all the raw data from the interviews was organized according to the research questions. The organized raw data is available as Supplementary Material (S1 and S2). The organized data was examined thoroughly and a compilation of the central answers and comments was created for the coding process (Appendix 5-Data Analysis by Research Questions). The coding was done by analyzing thoroughly the data and identifying themes and categories from the data. These identified themes can be seen in Appendix 6-Identified Themes from Data Analysis.

The data content in Appendices 5 and 6 are almost the same, however all data in Appendix 5 did not receive a clear identification and are thus not represented in Appendix 6. In addition, some answers and comments represent two identified themes and are therefore placed twice. The data was also analyzed across actors and between the case study and independent interviews in order to identify differences. Appendix 6 shows the molded themes which are described in more detail in the results chapter. The 
questionnaire results (Appendix 4) were used to verify the interview Questions 4 and 5 (Appendix 2). As the research questions are targeted for the whole life cycle data set, the results are presented as an entity.

Interpretation and interrelating the identified themes and research findings to each other was done through constructing the conceptual framework which synthetizes the findings together. The framework is presented in the results chapter.

\section{Results}

The results of this study are presented in four parts. First, the primary results according to the research questions are revealed. Second, significant differences between different actors are described. Third, differences between the case study and the independent interviews are presented. Fourth, a conceptual framework is presented. The framework is synthetized from the results to provide an overall understanding of the phenomenon and to highlight key findings of the study.

\subsection{Life Cycle Management in Urban Development}

Based on the data analysis it is clear that no actor takes responsibility of life cycle management in urban development. In this regard, the process is seen as fragmented and diffused and no actor is seen to have a genuine incentive for optimizing life cycle performance. There is a divided opinion on how life cycle management is to be implemented, some argue towards a joint effort, while the majority claims that one party should be responsible. Themes such as functionality and adaptability are identified to drive life cycle management through market value, as well as sustainable and durable design solutions.

Functionality and adaptability in the built environment are seen as key drivers for life cycle management in urban development. Many of the respondents point out that functionality is the factual value (and market value) of facilities in the built environment; hence, designing functional and adaptable premises with possibilities to adapt to changing needs in the future is seen as important. Design professions are criticized for insufficient understanding of life cycle impacts and encouraged to provide different design solutions along with their life cycle impacts as a prerequisite for decision-making. As no actor is actively in charge of life cycle management, steering design towards a life cycle performance is neglected. Additionally, actors within the operational phase claim that parties involved in development and design are not aware of the magnitude of operational maintenance costs over the life cycle. This subject should be explored to fully understand optimized life cycle thinking.

Sustainable and durable design solutions, materials and equipment are seen to create life cycle value. Achieving low maintenance costs and energy consumption are common targets for investors. Even though many investors have their own design guides for sustainable design, it is challenging to know what time periods to optimize because technical and commercial life cycles are seen differently. Additionally, life cycle design in urban developments is seen as challenging because of different life cycle functions. For example, retail premises and residential apartments have very different functional life cycles.

Three main reasons behind a lack of life cycle management could be found from the data: (1) business models are not aligned to optimize life cycle value; (2) interest conflicts between the public and private party; and (3) a lack of common targets throughout the development. 
Conflicts of interest between business models in urban development results in sub-optimization and does not incentivize a sustainable life cycle outcome. For example, uncoordinated design solutions and cost pressure on construction costs result in uncontrolled maintenance costs. Business models involved need to make profit continuously; therefore, additional investments (with longer pay-back time) are seen as unprofitable when calculated against the business models, instead of considering the urban development life cycle. Additionally, there is clearly a deficiency in understanding each other's business models which was also seen as a potential way to improve trust issues between actors.

Interest conflicts between the public and private actors were identified. There is clearly disagreement in who should be accountable for life cycle management, as the public sector represents the common good and the private party oversees economic viability. The private actors criticize the public authorities for lack a of life cycle thinking in zoning which has a significant effect on construction costs and the overall economic framework. Some public zoning authority actors admit the lack of comprehending economic feasibility and maintenance costs, and that it is the private actors who are responsible for "asset value management" during the life cycle. Tuned-up architectural demands result in higher investment costs which cannot be covered by market based rents and may delay or hinder urban development. On the contrary, the public sector claims that private actors are only interested in the generated cash-flow with a short-term business logic, compromising the quality of the built environment and thus guarding durability through zoning requirements.

As life cycle thinking is not embraced by all actors involved in the process, it is difficult to set common targets from a life cycle perspective, especially when there is not a clear responsible actor in charge for monitoring and ensuring life cycle targets are met. Common targets are also proposed due to conflicting targets between actors, for example, in order for contractors to respond to the investors' yield requirement, construction costs are reduced and life cycle thinking is further disregarded. The majority of the actors see that the investors are to be involved earlier in the urban development process in order to set targets from a life cycle perspective.

The concept of life cycle leadership advocated various underpinnings. The term life cycle leadership appeared clear and descriptive for the majority. Underpinnings stated that life cycle leadership should be controlled to minimize future uncertainties by looking "over" the project into the operational phase. The majority thought that one party is to be responsible and take the leadership role and that execution is a joint value co-creation effort to be included in the urban/property development process.

Various actors declared that there is a demand for life cycle leadership, as some investors claimed that they are the life cycle "leaders". A contrary opinion was stated by a residential fund investor; "no leadership is required, everyone in the value chain should understand their position as the producer is responsible for the product". The roles of co-creation and trust were seen as substantial and that life cycle leadership should be more strongly demanded by the client. Another residential investor quoted the following concerning life cycle leadership: "Sounds more expensive and holistic, if life cycle leadership would be executed consistently it would mean large savings in the long-run and sustainability would be enhanced through this model, a desirable and appropriate ideology for public investment entities". 


\subsubsection{Responsibility of Life Cycle Management}

It is evident based on the data that investors and owners should be responsible for life cycle management in urban development. This argument is derived from the fact that the owner is the one who makes decisions because of their capital commitment. Some respondents declare that when investors are involved in the development there is a life cycle perspective to be recognized. The investors should consider the life cycle of the building and demand life cycle performance more strongly.

While, various actors indicate investors as responsible for life cycle, they correspondingly question the investment horizon and strategy of the investment period. Institutional investors with long term strategies are seen as life cycle supportive, whereas real estate funds with short investment horizons do not see life cycle management beneficial because additional investments are not within their planned ownership period, and pay-back for the investment would be gained by the next owner. In addition, some actors criticize investors for only focusing on the cash-flow of buildings instead of considering the larger sustainability scope. The residential investors with shorter investment periods claimed that the producer (i.e., contractor and/or developer) is the one who should be responsible for the life cycle outcome.

Investors have identified and performed additional investments which result in lower maintenance costs and lower energy consumption, however, this analogy has not been taken further to achieve its full potential.

Investors' earlier involvement is requested by the other actors, although the problem for the investors seems to lie in resourcing. Investors have thin development organizations and rely on developers to bring them projects that are almost ready. Investors can commit resources and capital only when enough users are involved, and at that point designs are at a late stage and difficult to change to support a sustainable life cycle perspective. Thus, investors rely on the market to bring them ready life cycle optimized developments, even though they should be the responsible party.

\subsubsection{Added Value through Life Cycle Management}

The interview data (verified by the questionnaire) show that there is definitely added value to be created within various business models and in urban development. However, it seemed very unclear how this added value is to be properly measured, controlled and facilitated. Examples of added value were improved maintenance (resource and cost efficient), energy-efficiency and better living quality.

The primary identified value was economic through long term savings. Ecological and social savings were similarly identified, but economic value and potential influence on market value was perceived as primary. Numerous respondents identified a viability link from economic value to environmental and social value. Added value to improve market value was exemplified through diminishing operational and capitalizing the difference to increase market value. Citation from an investor: "If the real estate consumes 50 cent less in O\&M costs we can allocate it to the capital lease (tenant pays total lease) which means that the real estate value rises by $2 \%-3 \%$ which means that $100 \mathrm{M} €$ real estate becomes $103 \mathrm{M} €$ !”. Still, the economic significance of rent levels and their maturity of rental leases are far superior and naturally prioritized. Value through life cycle management may also come from decreasing life cycle risk by active O\&M activities and sufficient funding of the long term maintenance plan. As a retail investor quoted: "The starting point should be the life cycle plan, investing in this does not increase net operating income, but rather prevents it from falling". 


\subsubsection{Tools to Enhance Life Cycle Management}

The role of tools in advancing life cycle management in the data is seen as supportive and secondary. Existing tools were considered undeveloped and practically inapplicable. The challenge with these tools was seen as their proficiency in justifying value. Validity and credibility of the tools was questioned when portraying an uncertain future. Very few actors actually used these tools and often in special cases. The interviewed stated that tools should be developed to be comparable, transparent, entail common measures and should have a common status of approval. Common targets should be the starting point for development of supportive tools.

The key method to improve life cycle management was considered to be enhancing co-operation between different partners in the early planning phase. Integrated design process and stronger co-operation between designers, contractors and facility management providers were seen as important and creating value adding synergies. An open and transparent negotiation framework was suggested in order to ratify common life cycle targets and align individual business targets accordingly. Additionally, a systematic, seamless and logical process for facilitation was called for.

Building (and general) information management was seen as a highly promising additional source of value. Meanwhile, different types of certifications were not considered helpful, because their value is connected to real estate transactions which are not a part of every investor's strategy. To conclude, nearly all interviewed would be willing to invest in measures to enhance life cycle management.

\subsection{Differences between Actors Regarding Life Cycle Management}

The actors analyzed across each other in this study were public authorities, private actors (consultants, developers, contractors, retail tenants, property managers) and different kinds of property investors (residential, public, office, mixed, retail).

One major difference identified between the public and private actors was the perception of life cycle in urban development. The public authorities understanding of life cycle, not surprisingly, is far more extensive than private actor's viewpoint. Zoning of urban areas is performed with a long life cycle perspective; an interviewed zoning director quoted: "A city is planned for 1000 years, a cornerstone in urban development". However, investors and tenants convey that it is not always beneficial to define a lifespan and that there is a major difference between technical and commercial life cycles.

Investors (and a few consultants and contractors) have criticized public zoning authorities for limited and insufficient understanding of life cycle impacts in zoning. Some zoning respondents have admitted that they do have a lack of understanding in that sector and no sufficient tools for life cycle perspective are utilized. Still, through legislation they are responsible for the quality in the built environment and need to control and ensure certain aspects for the future. As the zoning authorities create the guidelines for the built environment, the economic framework is simultaneously outlined which is then "handed over" to the private sector for execution and maintenance - a great deal of co-operation is needed. A residential investor quoted: "Zoning follows sustainability targets, but forces towards certain solutions, thus locking $50 \%-60 \%$ of construction costs".

The final significant difference between actors was institutional and real estate fund investors' perceptions of life cycle management. This was recognized by investors and other actors along the development chain. Investors with shorter investment periods did not see explicit benefits through life 
cycle management, while institutional and long-term investors considered life cycle management as a part of their strategy. The real estate fund investors claimed, that in their case, the producer (i.e., developer and contractor) is the party who should take the responsibility of the life cycle outcome and as investors they are to concentrate on their core competence which is investing and not developing.

\subsection{Differences between the Case Study and Independent Interviews}

All in all, the content of the case study and the set of independent urban development interviews were highly aligned. However, a few differences were perceived.

In the case study, a negotiation framework for improving communication, coordination and common interests was required by numerous interviewees. The intent of this negotiation framework is to facilitate and commonly agree upon project targets between all actors to improve value co-creation. Life cycle targets would naturally be a part of this negotiation and target-setting. The motive behind this initiative is the different business models involved and the challenge of aligning these to identify and agree upon common interests. An interview representing the contractor quoted: "All should 'bargain' with their costs to achieve life cycle value".

A perception of new business opportunities around life cycle management was elevated from the independent interviews. These new business opportunities were recognized by various actors due to the fragmentation of the development chain, especially between development and the operational phases. Some stated that contractors should take on a greater responsibility in the operational phase. Facility management providers identified business potential through extended life cycle responsibility and extending backwards towards consultation in the design phase. Overall, integration possibilities between design, construction and facility management were seen as lucrative from a life cycle perspective. Additionally, an urban design management role (i.e., system integrator) was considered by the city in order to maintain coordination in early phases of urban development. A public party interviewee stated: "There is a clear need for life cycle leadership, but is there a clear demand?".

\subsection{A Conceptual Framework for Life Cycle Management in Urban Development-Key Findings}

A conceptual framework was synthetized from the research results to present key findings and provide a more holistic understanding of life cycle management in urban development. The research questions of the study are included in the framework in order to link themes and content in the framework. The conceptual framework can be seen in Figure 1.

The conceptual framework (Figure 1) presents the key findings interlinked with each other. The blue boxes represent the current state of how life cycle management is perceived at the present. The yellow boxes indicate themes through which life cycle management in urban development can be improved.

The current state is that no actor takes responsibility for life cycle management in urban development. The main reasons are: business models are unsuccessfully aligned to better support life cycle value creation, interest conflicts between public and private sector, and lack of common (life cycle) targets throughout the development. The results reveal that property investors and owners should be responsible for the life cycle outcomes and promote life cycle management by improving market value through functionality and adaptability of the properties. Since there is value to be created by enhancing life cycle management, it is essential that tools are developed to genuinely rationalize value creation and 
consequently increase market value. Tools are also to be developed to set and follow common targets with a life cycle approach. In regard to value creation, mechanisms are needed to share value between involved business models in order to facilitate co-creation of life cycle value. The framework indicates that if the property investors and owners would undertake a stronger role as the life cycle "leader" this would enable improved tools and mechanisms, and initiate a more tangible approach for life cycle management in urban development.

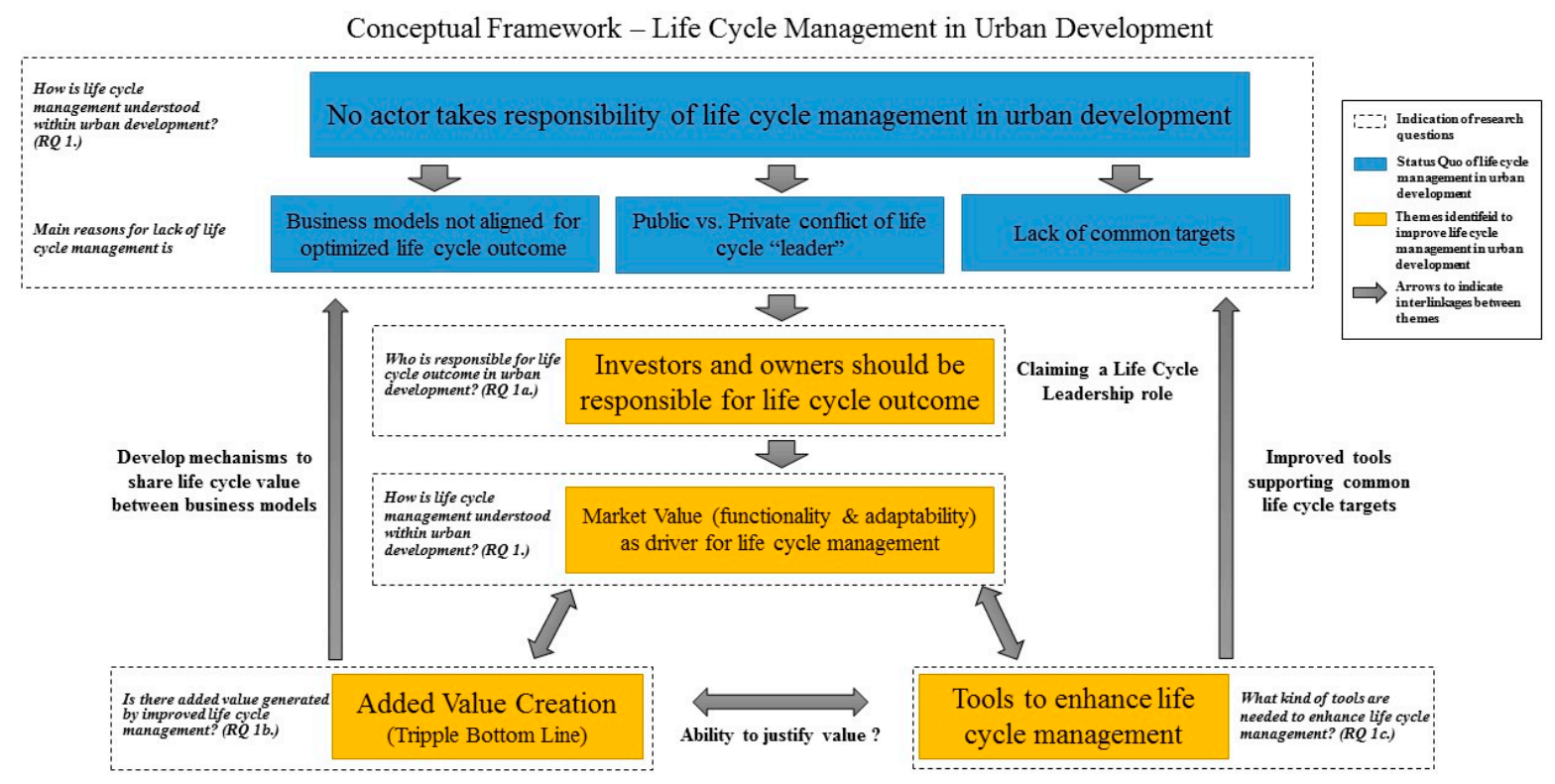

Figure 1. Conceptual framework of life cycle management in urban development.

\section{Discussion}

The intent of this study was to examine how life cycle management was understood in urban development. The results show that there is a lack of life cycle management since no actor claims life cycle responsibility. However, key actors within urban development claim that there is added value in terms of sustainability to be created by obtaining a life cycle approach.

This finding is significant, since the construction and property industry is one of the largest business activities in most economies and still the ability to see into the future is poor, even if strategic planning is considered highly in the real estate sector $[21,45]$. Therefore, there appears to be hidden value to be harvested through the life cycle management approach. In addition, similar findings has been indicated in different phases of the urban development process, where no process owner is identified and gaps in life cycle activities have been recognized [13,46-48]. This further strengthens the view that the urban development process is fragmented and the actors involved are maximizing their own business, resulting in sub-optimization, thus creating unsustainable solutions from a life cycle perspective [12-14].

The identified main reasons for lack of life cycle management are also mentioned in existing literature. Lack of common measures has been identified $[13,46]$; for example Väyrynen states in her dissertation that a coherent urban development process should have well-defined, accurate and measurable targets derived from common goals [13]. The current conflict between public and private sector regarding the life cycle "leader" is an interesting discussion. This study reveals that the private sector (property investors) should be the life cycle "leader" because of their long term commitment. 
However, the public parties responded that they should have a certain influence as they represent the common good and are accountable for legislative aspects in urban planning. Some authors share the view that the public sector is to be responsible due to legislation $[13,49]$, while others state that the public interest cannot be the only objective, and that other stakeholders are to be involved when defining common goals [50]. Similar responsibility challenges have been identified within sustainable global water governance by the organization of economic co-operation and development (OECD). To manage future development, the OECD has initiated principles on three joint complementary dimensions; effectiveness, efficiency, and trust and engagement. Through effectiveness, clear sustainable public policy targets are defined, efficiency refers to maximizing benefits of sustainable water management, and trust and engagement builds public confidence and includes all stakeholders through democratic legitimacy [51].

Numerous interviewees emphasized improved understanding of each other's business models and viewpoints in order to work better together and jointly creating solutions. This view is also shared by Camillus [52]. The challenge of aligning business models to optimize life cycle outcome to create value has been discussed as the concept of integrated solutions combining products and services as a life cycle offering to match customers' requirements. Brady et al. suggest that integrated solutions will constitute the base for business models in the future [15]. Several authors have claimed that long-term value can be gained through a life cycle solution/offering both for the customer and supplier [53-55]. However, it remains to be seen if businesses are able to modify their business models. A study by Leiringer et al. reveals that construction companies are not likely to reshape their business to meet the "value agenda" [18].

A significant finding of this study is that property investors and owners should be responsible for life cycle outcome and performance in urban development. Due to limited resources investors and owners partially outsource this to developers and other actors resulting in divided ownership of the process. Therefore, the investor should assume a system integrator role identified by Winch in construction management. However, since the system integrator role is split by the principal architect and contractor, a whole life cycle approach is challenging to obtain since property and facility management are disintegrated from the management [17]. A similar central actor is proposed by Weber and Khademian; a collaborative capacity builder who should have a long term commitment and be able to link horizontally and vertically in the ecosystem [56].

Life cycle management is to be driven by enhancing market value of the properties by improving functionality and adaptability. In order to enhance sustainable development through life cycle management, life cycle performance is to be included as an accentuated parameter for valuation of properties. Lützkendorf and Lorenz declare that sustainability indicators will have a stronger role in commercial property valuation and that life cycle performance should similarly be assessed [19]. Lützkendorf and Lorenz propose requirements for sustainable buildings where maximizing functionality and serviceability is naturally considered along with life cycle performance such as minimizing life cycle costs, reducing $\mathrm{CO}_{2}$ emissions and other impacts to the environment [21]. If life cycle management is to attain a more convincing position, life cycle value needs to be clearly recognized in valuation standards in order to genuinely affect decision-making.

The results of this study reveal that all actors within urban development see that there is definitely more value to be created by enhancing life cycle management (Appendix 4-questionnaire results). Value is created in the form of improved maintenance (resource-and cost efficiency), energy-efficiency 
and improved living quality. Similar findings regarding life cycle savings from sustainable design are reported by Kats et al. [22].

Still, the challenge lies in measuring, controlling and facilitating this added value. Although life cycle management methodology offers different life cycle sustainability assessment (LCSA) tools [35,36] for economic, environmental and social evaluation, it appears that potential added life cycle value is not tangible enough for the industry to comprehend and is thus overlooked in decision-making. A recent study examining both economic and ecological life cycle outcomes of a residential district energy design reveals that cost and emission savings are possible to identify through life cycle assessment methods, however, a life cycle approach is not traditionally utilized in decision-making [37]. In addition, many respondents questioned the ability to justify value for the uncertain future. Therefore, tools utilized for life cycle management should be developed to be more practical and easily communicated and to support life cycle target setting of the development.

Additionally, the respondents emphasized that if life cycle value is created together within the ecosystem, there should also be mechanisms in place to share the captured added value accordingly. This discussion links directly to the alignment of business models and creating suitable mechanisms and incentives for enhancing life cycle value. Saxon looks to new business models and integrated solutions as the foundation for life cycle value creation [57].

\subsection{A Concept for Life Cycle Leadership?}

In light of the research findings, a life cycle leadership concept is proposed. An acknowledged leadership position would clarify the life cycle responsible and the owner of the development, a similar role as the system integrator and collaborative capacity builder [17,56]. The life cycle leader would account for arranging business models and incentives towards a life cycle value agenda and define common life cycle targets accordingly. These undertakings would certainly advance the development of practical tools for life cycle management and comprehension of measuring life cycle value. In addition, a life cycle leadership concept would decrease fragmentation and sub-optimization within the urban development process, simultaneously strengthening co-creation and trust between the actors. The property investor/owner should claim this leadership role and define the contents accordingly, as the proposed responsible actor of life cycle management in urban development.

Koskela et al. recognize a lack of through-life management in large scale procurements which can be understood as analogous to the life cycle leadership concept [20]. The initiatives presented by Koskela et al. are focused towards a life cycle approach in terms of cost, design, analysis, capital, value and decision-making [20].

As one interviewed appropriately quoted: "There is a clear need for life cycle leadership, but is there a clear demand?" Perhaps, the urban development sector has not yet recognized the full potential of a life cycle approach and the added value in terms of sustainability. Therefore, a life cycle leadership concept needs to be acknowledged in order to initiate progress and renew our urban development process.

\subsection{Validity and Reliability of the Research}

Examining accuracy of the research findings and evaluating consistency of the research process is imperative when determining the credibility of the research [25]. The research as an entity is challenging 
to compare against prior research since life cycle management in urban development has not been examined in the ecosystem context before. However, concepts presented in the conceptual framework (Figure 1) are dealt within the discussion part and identified in existing academic literature, thus strengthening reliability of the research findings.

The validation strategies utilized are a triangulation between the case-study, independent interviews, verifying questionnaires and time spent as a participant observer in the case-study. It is important to declare that the researcher started the interviews after the participant observation time and distinctly clarified his role as a neutral academic interviewer in order to disclose biases. As similar issues were emphasized by different actors through different data sources, a high level of triangulation was obtained.

Regarding the research process, the interview data was coded according to the qualitative data analysis stages presented by Creswell [25]. The data was coded to identify themes and categories across actors (open coding), and actors were analyzed across the research questions (axial coding). The data analysis was conducted in an interactive fashion going back and forth between the identified themes and the raw data to establish consistency. The case-study and independent interviews were analyzed separately in order to identify differences. Still, it is important to point out that interpretation errors may have occurred during the interviews and in analyzing the data. Especially, as the interview data was coded by hand, researchers' biases are to be considered in assessing the validity of the study [25].

The questionnaire was not analyzed in a statistical fashion due to an embedding and verifying role to support the qualitative interview data. As an independent survey sample size, 38 surveys within the urban development industry would not be representative enough. Therefore, the survey's role of supporting the qualitative interviews is highlighted as a mixed methods approach [25].

The empiric data presented in this research is significant and versatile because of the ecosystem and urban development scope. The case-study presents one of Finland's significant urban developments in the metropolitan area and the set of independent interviews includes major cities' public representatives, key business actors and approximately $63 \%$ on the Finnish property investment market 2014 [44].; thus, representing a national urban development ecosystem.

The conceptual framework (Figure 1) of this study presents the theoretical contribution as interlinked concepts of the phenomenon describing the current situation and proposing development actions. In the conceptual framework analysis, it is to be noted that researchers may have different perspectives of the phenomenon resulting in different outcomes. However, the flexibility and capacity of modification are seen as advantages in conceptual frameworks [40].

In terms of generalization, key findings and the conceptual framework can be utilized globally in economies with similar urban development practices and actors, as concepts were identified in the literature. In terms of limitations, if venturing outside the scope of urban development, the specific industry characteristics are to be carefully considered. Since the agenda of this research is to address sustainable urban development from a life cycle perspective, the implications for urban sustainability are to be considered and utilized for further research.

\section{Conclusions}

Sustainable urban development presents a grand opportunity to mitigate climate change and improve sustainability, as cities and the global building stock are responsible for the majority of carbon emissions 
and energy consumption. However, current urban development practices do not incorporate a life cycle perspective; the process is fragmented and sub-optimization results in an unsustainable life cycle outcome. A life cycle management approach is disregarded and potential sustainable value throughout the life cycle of urban development is lost.

This study reveals that no actor takes responsibility for life cycle management in urban development due to conflicts between the public and private sector, unsuccessful alignment of business models and clear target setting. Although, all the involved actors claim that there is value to be created, mostly in economic but also environmental and social terms. The results clearly identify property investors and owners as the responsible actors for life cycle management in urban development. Life cycle management is to be driven by functionality and adaptability to enhance market value for investors and owners. As a result of this study, a life cycle leadership concept is proposed for investors and owners to orchestrate the urban development process, thus decreasing fragmentation and increasing trust and co-operation between actors. Life cycle responsibility would include alignment of business models and incentives towards common life cycle targets. These improvements would result in developing practical life cycle management tools to genuinely justify value along the life cycle.

The conceptual framework (Figure 1) presented in this study provides an overall understanding of the challenges and opportunities of life cycle management in urban development. The conceptual framework is recommended for actors and practitioners within urban development, as well as in advancing theoretical contributions in academia. For urban development, a holistic and coherent life cycle approach would result in an improved life cycle outcome in terms of sustainability. Thus, there is significant potential to respond to the urban sustainability challenge.

This study comprises a comprehensive sample of key actors from the Finnish urban development industry. Therefore, generalization is limited to the scope of urban development with similar market conditions and characteristics. Many of the actors are also active in the Nordic property development market.

Life cycle responsibility is proposed in order to improve life cycle management in urban development. Recommended further research should investigate and validate how measures applied by the life cycle "responsible" affects the outcome of the conceptual framework. Is the claimed added value captured, are tools for life cycle management developed and utilized, and does the life cycle approach result in a more coherent, sustainable urban development process?

\section{Acknowledgments}

The authors would like to express their gratitude to The Finnish Association of Building Owners and Construction Clients (RAKLI), Agne Sandberg Foundation (Skanska AB) and Kiinko Real Estate Education for financial support of this research.

\section{Author Contributions}

Miro Ristimäki is responsible for initiating, executing and writing this article. Seppo Junnila has provided comments and suggestions to the article. 


\section{Conflicts of Interest}

The authors declare no conflict of interest.

\section{Appendix 1-List of Interviewees}

\begin{tabular}{|c|c|c|c|c|c|c|c|}
\hline & \multicolumn{3}{|c|}{ Actor in Urban Development } & \multicolumn{2}{|l|}{ Title } & Date & Data \\
\hline 1 & \multicolumn{3}{|l|}{ Developer } & \multicolumn{2}{|l|}{ Development Director } & 30.9 .2014 & Case Study \\
\hline 2 & \multicolumn{3}{|l|}{ Tenant } & \multicolumn{2}{|c|}{ Development Manager } & 5.11 .2014 & Case Study \\
\hline 3 & \multicolumn{3}{|l|}{ Public Authority } & \multicolumn{2}{|l|}{ Chief of Zoning } & 5.11 .2014 & Case Study \\
\hline 4 & \multicolumn{3}{|l|}{ Public Authority } & \multicolumn{2}{|c|}{ Real Es tate Development Manager } & 7.11 .2014 & Case Study \\
\hline 5 & \multicolumn{3}{|l|}{ Tenant } & \multicolumn{2}{|c|}{ Development Manager } & 11.11 .2014 & Case Study \\
\hline 6 & \multicolumn{3}{|c|}{ Consultant (Commercial) } & \multicolumn{2}{|l|}{ Commercial Director } & 26.11 .2014 & Case Study \\
\hline 7 & \multicolumn{3}{|l|}{ Developer } & \multicolumn{2}{|c|}{ Sustainability Manager } & 26.11 .2014 & Case Study \\
\hline 8 & \multicolumn{3}{|c|}{ Consultant (Traffic Designer) } & \multicolumn{2}{|c|}{ Senior Traffic Designer } & 28.11 .2014 & Case Study \\
\hline 9 & \multicolumn{3}{|c|}{ Consultant (Architect) } & \multicolumn{2}{|l|}{ Arcitect, Partner } & 14.1 .2015 & Case Study \\
\hline 10 & Developer & & & Development Direct & (Residential) & 15.1 .2015 & Case Study \\
\hline 11 & Contractor (Residen & ntial) & & Design Director (Res & dential) & 20.1 .2015 & Case Study \\
\hline 12 & Contractor & & & Construction Directc & & 2.2 .2015 & Case Study \\
\hline 13 & Consultant (Project & Manageme & ent) & Managing Director & & 5.2 .2015 & Independent Interview \\
\hline 14 & Consultant (Sustain & nability) & & Partner & & 6.2 .2015 & Independent Interview \\
\hline 15 & Facility Managemen & nt Services & & Chief Operating Offi & & 17.2 .2015 & Independent Interview \\
\hline 16 & Investor - Mixed & & & Construction Manas & & 23.2 .2015 & Independent Interview \\
\hline 17 & Property Manageme & ent Services & & FM Director & & 26.2.2015 & Independent Interview \\
\hline 18 & Investor - Public & & & Development Direct & & 3.3 .2015 & Independent Interview \\
\hline 19 & Investor - Mixed & & & Real Estate Develop & ent Director & 10.3 .2015 & Independent Interview \\
\hline 20 & Investor - Office & & & Real Estate Manage & ent Director & 11.3 .2015 & Independent Interview \\
\hline 21 & Investor - Residenti & & & Managing Director & & 13.3 .2015 & Independent Interview \\
\hline 22 & Investor - Residenti & & & Real Estate Develop & ent Director & 18.3 .2015 & Independent Interview \\
\hline 23 & Investor - Mixed & & & Real Estate Develop & ent Director & 8.4 .2015 & Independent Interview \\
\hline 24 & Investor - Public & & & Investment Director & & 13.4 .2015 & Independent Interview \\
\hline 25 & Investor - Mixed & & & Real Estate Investme & Director & 14.4 .2015 & Independent Interview \\
\hline 26 & Public Authority & & & Chief of Zoning & & 15.4 .2015 & Independent Interview \\
\hline 27 & Public Authority & & & Head of Urban Planr & ng Department & 20.4 .2015 & Independent Interview \\
\hline 28 & Investor - Retail & & & Real Estate Develop & ent Director & 22.4 .2015 & Independent Interview \\
\hline 29 & Investor - Residenti & & & Real Estate Develop & ent Manager & 27.4 .2015 & Independent Interview \\
\hline 30 & Investor - Retail & & & Managing Director & & 12.5 .2015 & Independent Interview \\
\hline 31 & Public Authority & & & Technical Director & & 13.5 .2015 & Independent Interview \\
\hline 32 & Public Authority & & & Technical Director & & 18.5 .2015 & Independent Interview \\
\hline 33 & Consultant (Constru & uction Man & agement) & Managing Director & & 19.5.2015 & Independent Interview \\
\hline 34 & Public Authority & & & Head of Real Estate & epartment & 19.5.2015 & Independent Interview \\
\hline 35 & Property Manageme & ent Services & & Managing Director & & 21.5 .2015 & Independent Interview \\
\hline 36 & Investor - Mixed & & & Project Director & & 25.5 .2015 & Independent Interview \\
\hline 37 & Investor - Mixed & & & Real Estate Investme & Director & 27.5 .2015 & Independent Interview \\
\hline 38 & Investor - Residenti & & & Chief Analyst & & 27.5 .2015 & Independent Interview \\
\hline & & Intervieweed & Actor Typology & & Allocation between & I private actors & \\
\hline & & 7 & Public aurhority & & $18 \%$ Public actors & & \\
\hline & & 3 & Developer & & $82 \%$ Private actors & & \\
\hline & & 2 & Contractor & & & & \\
\hline & & 6 & Consultants & & & & \\
\hline & & 2 & Retailers & & & & \\
\hline & & 3 & FM providers & & & & \\
\hline & & 4 & Residential invest & & & & \\
\hline & & 2 & Public investors & & & & \\
\hline & & 1 & Office investor & & & & \\
\hline & & 6 & Mixed investors & & & & \\
\hline & & 2 & Retail investors & & & & \\
\hline
\end{tabular}

\section{Appendix 2-Interview Questions}

\section{Interview Framework-Life Cycle Management in Urban Development}

1. Analyze each stakeholder positioning within the ecosystem along with its characteristics

- What is your role/position in this ecosystem (case)? 
- What is your business model-How do you create and capture value?

2. Perception of Life Cycle Concept

- How do you understand the concept of Life Cycle Thinking/Approach?

- How is life cycle thinking/approach seen in your business model

- How is life cycle thinking/approach seen in the whole value chain

- How do you understand the concept of Life Cycle Leadership?

3. Responsibility of Life Cycle Management in Urban Development

- Do you see that there is a clear responsible actor for the life cycle of the real estate/urban area?

- If not, who should it be and why?

4. Creating Value through Life cycle Management

- Do you see that there is value to create and capture through improving Life Cycle Management/Thinking/Approach?

- If yes, what kind of value?

○ Economic

○ Environmental

○ Social

O Other?

5. What kind of tools would be relevant in enhancing life cycle management?

- Examples...

○ Life cycle assessment tools

- Contractual and Procurement models

- Financial models

Information flow (BIM)

○ Certification tools

\section{Appendix 3-Questionnaire}

Questionnaire to verify with interview Questions 4 and 5

Questionnaire for examining Life Cycle Management in Urban Development

1. Does enhancing life cycle management create more value to your business model?

$$
\text { Yes/No }
$$

If yes, what kind of value?

Economic

Yes/No

Environmental

Yes/No

Social

Yes/No

Other? Examples?

2 Does enhancing life cycle management create more value Real Estate/Urban Development?

$$
\text { Yes/No }
$$

If yes, what kind of value?

Economic Yes/No

Environmental Yes/No 
Social

Yes/No

Other? Examples?

3 Would you be willing to Invest in measures for enhancing Life Cycle Management?

Yes/No

4. In what kind of measures would you be willing to invest/develop in?

Life cycle assessment tools

Yes/No

Contractual and Procurement models

Yes/No

Financial models

Yes/No

Information flow (BIM)

Yes/No

Certification tools

Yes/No

Others? Examples?

\section{Appendix 4-Questionnaire Results}

\begin{tabular}{|c|c|c|c|c|c|c|c|c|c|}
\hline \multirow[t]{2}{*}{ Questionnaire Results } & \multicolumn{3}{|c|}{ Case Study } & \multicolumn{3}{|c|}{ General Interviews } & \multicolumn{3}{|c|}{ All data } \\
\hline & Yes & No & No Answer & Yes & No & No Answer & Yes & No & No Answer \\
\hline 1. Does enhancing life cycle management create more value to your business model? & $100 \%$ & $0 \%$ & $0 \%$ & $96 \%$ & $4 \%$ & $0 \%$ & $97 \%$ & $3 \%$ & $0 \%$ \\
\hline \multicolumn{10}{|l|}{ If yes, what kind of value? } \\
\hline Economic & $92 \%$ & $0 \%$ & $8 \%$ & $96 \%$ & $0 \%$ & $4 \%$ & $95 \%$ & $0 \%$ & $5 \%$ \\
\hline Environmental & $100 \%$ & $0 \%$ & $0 \%$ & $92 \%$ & $4 \%$ & $4 \%$ & $95 \%$ & $3 \%$ & $3 \%$ \\
\hline Social & $75 \%$ & $8 \%$ & $17 \%$ & $81 \%$ & $12 \%$ & $8 \%$ & $79 \%$ & $11 \%$ & $11 \%$ \\
\hline 2. Does enhancing life cycle management create more value in real estate/urban development & $100 \%$ & $0 \%$ & $0 \%$ & $100 \%$ & $0 \%$ & $0 \%$ & $100 \%$ & $0 \%$ & $0 \%$ \\
\hline \multicolumn{10}{|l|}{ If yes, what kind of value? } \\
\hline Economic & $92 \%$ & $0 \%$ & $8 \%$ & $100 \%$ & $0 \%$ & $0 \%$ & $97 \%$ & $0 \%$ & $3 \%$ \\
\hline Environmental & $100 \%$ & $0 \%$ & $0 \%$ & $92 \%$ & $4 \%$ & $4 \%$ & $95 \%$ & $3 \%$ & $3 \%$ \\
\hline Social & $92 \%$ & $0 \%$ & $8 \%$ & $88 \%$ & $4 \%$ & $8 \%$ & $89 \%$ & $3 \%$ & $8 \%$ \\
\hline 3. Would you be willing to invest in measures for enhancing life cycle management? & $92 \%$ & $8 \%$ & $0 \%$ & $92 \%$ & $8 \%$ & $0 \%$ & $92 \%$ & $8 \%$ & $0 \%$ \\
\hline \multicolumn{10}{|l|}{ 4. In what kind of measures would you be willing to invest/develop in? } \\
\hline Life cycle assessment tools & $83 \%$ & $8 \%$ & $8 \%$ & $85 \%$ & $12 \%$ & $4 \%$ & $84 \%$ & $11 \%$ & $5 \%$ \\
\hline Contractual \& Procurement models & $50 \%$ & $8 \%$ & $42 \%$ & $85 \%$ & $8 \%$ & $8 \%$ & $74 \%$ & $8 \%$ & $18 \%$ \\
\hline Financial models & $33 \%$ & $25 \%$ & $42 \%$ & $42 \%$ & $35 \%$ & $23 \%$ & $39 \%$ & $32 \%$ & $29 \%$ \\
\hline Information flow (BIM) & $83 \%$ & $0 \%$ & $17 \%$ & $77 \%$ & $12 \%$ & $12 \%$ & $79 \%$ & $8 \%$ & $13 \%$ \\
\hline Certification tools & $42 \%$ & $25 \%$ & $33 \%$ & $54 \%$ & $27 \%$ & $19 \%$ & $50 \%$ & $26 \%$ & $24 \%$ \\
\hline
\end{tabular}


Appendix 5-Data Analysis by Research Questions

\begin{tabular}{|c|c|c|c|c|c|c|c|c|c|c|c|c|c|}
\hline & \multicolumn{5}{|c|}{ Case Study (12) } & \multicolumn{8}{|c|}{ General Interviews (26) } \\
\hline & City authority / Zoning (2) & Developers (3) & Consultants (3) & Contractors (2) & Retail tenants (2) & City authority / Zoning (5) & Consultants (3) & $\begin{array}{c}\text { Property Management } \\
\text { Services (3) }\end{array}$ & Residential Investors (4) & Public Investors (2) & Office Investor (1) & Mixed Investors (6) & Retail Investors (2) \\
\hline $\begin{array}{l}\text { Life cycle management in } \\
\text { urbann development }\end{array}$ & 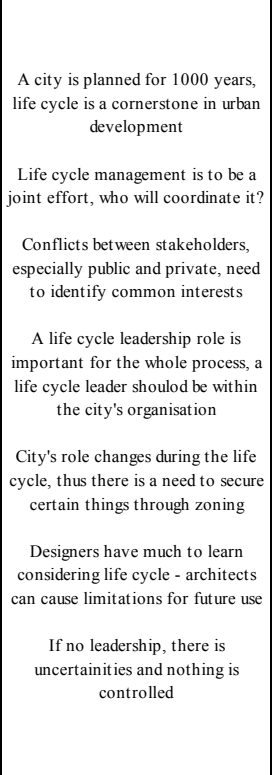 & 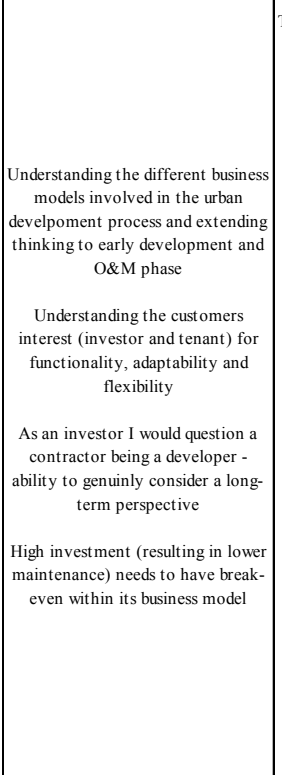 & 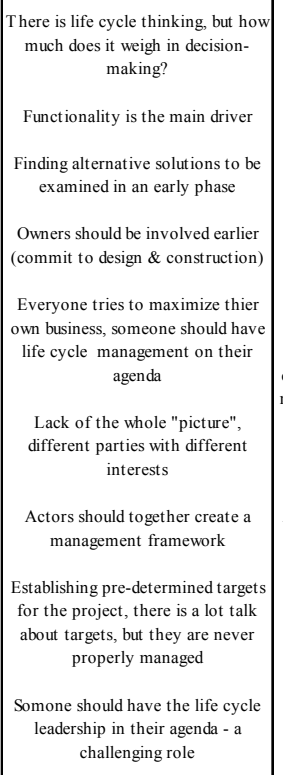 & 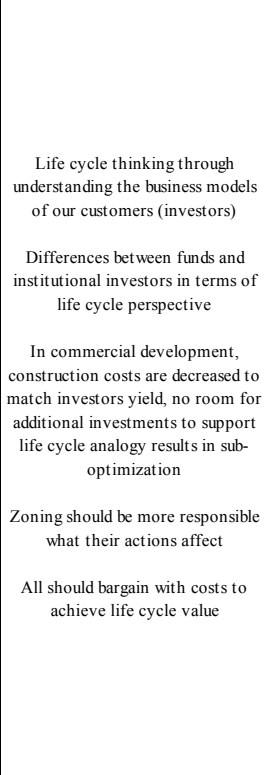 & 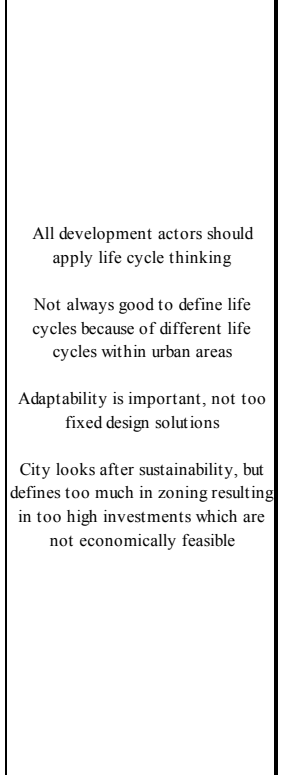 & 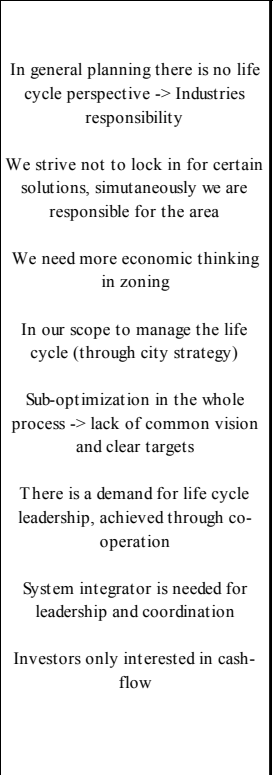 & 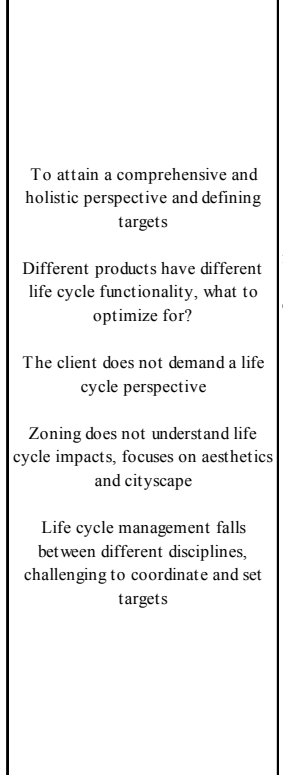 & 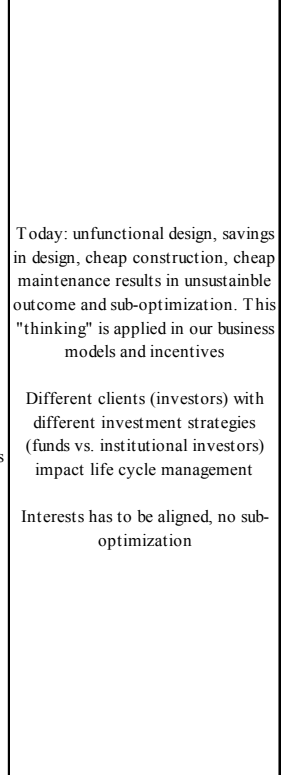 & 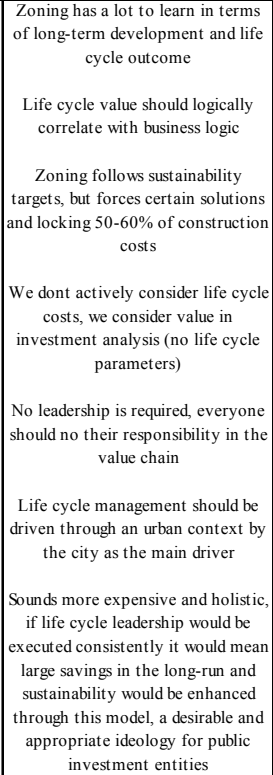 & 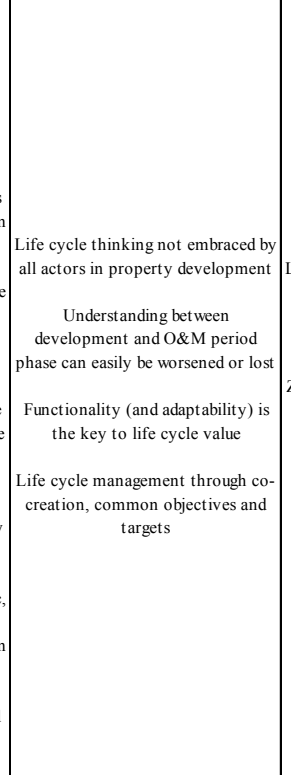 & 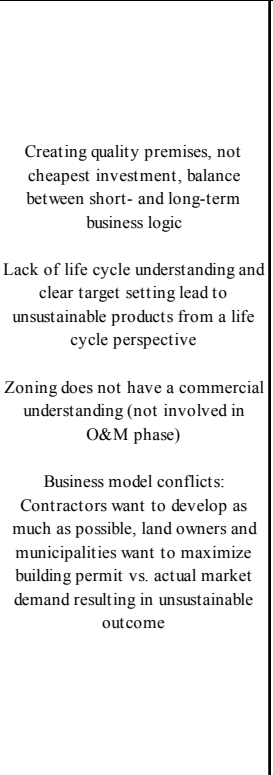 & 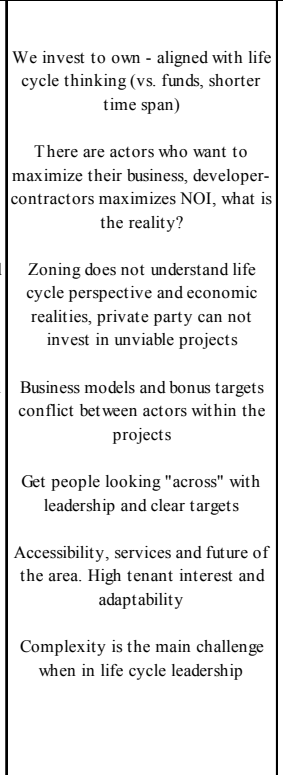 &  \\
\hline $\begin{array}{c}\text { Responsibility of life cycle } \\
\text { management }\end{array}$ & 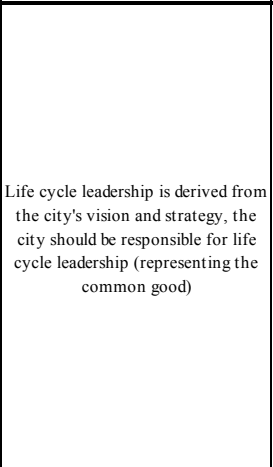 & 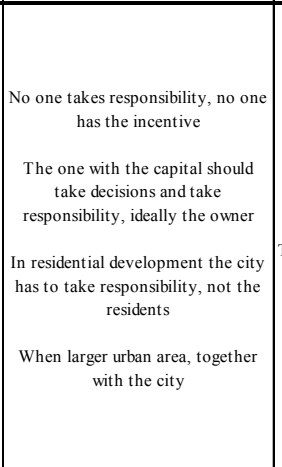 & 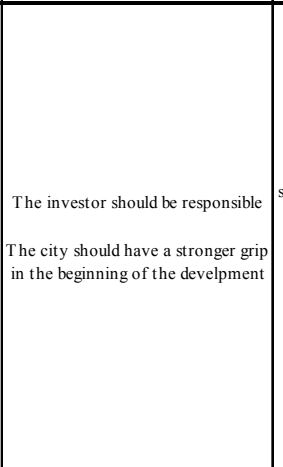 & $\begin{array}{l}\text { No, there is not aresponsible } \\
\text { stakeholder yet, as solog as we are in } \\
\text { search for an investor } \\
\text { Now the responsibility is with the } \\
\text { developer, investor should enter } \\
\text { earlier }\end{array}$ & 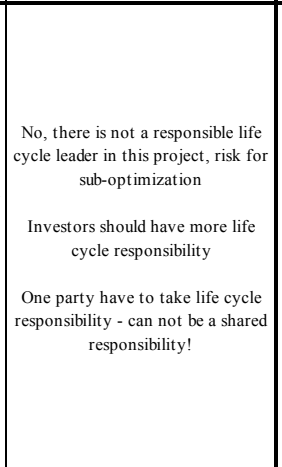 & 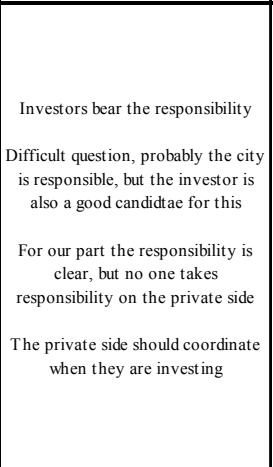 & 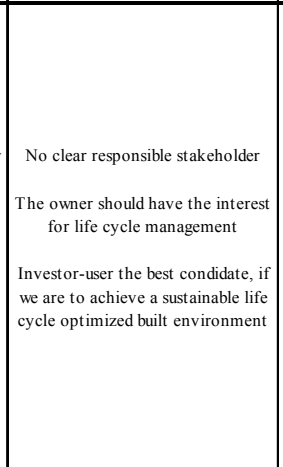 & $\begin{array}{c}\text { Investor should take the } \\
\text { responsibility } \\
\text { No one is responsible for life cycle, } \\
\text { very splited in the beginning } \\
\text { There is ifie cycle eadership when } \\
\text { the owmer is involved }\end{array}$ & 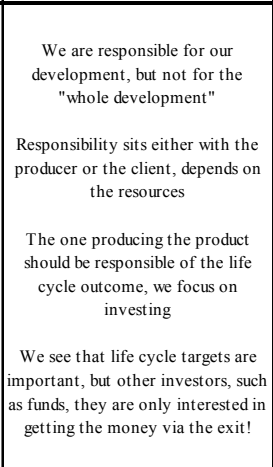 & 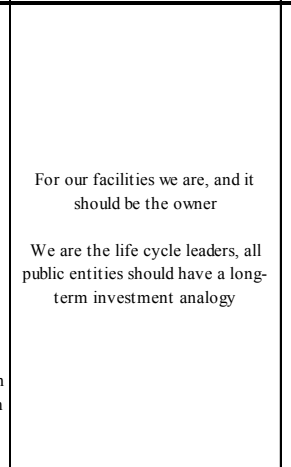 & 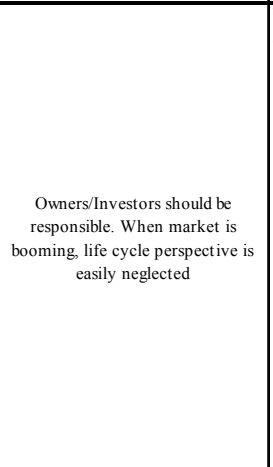 & 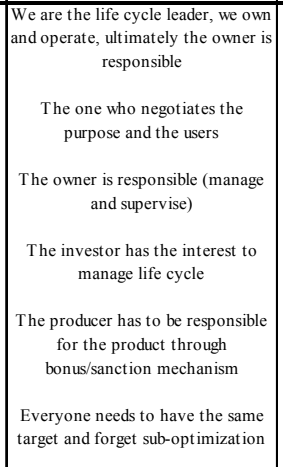 & 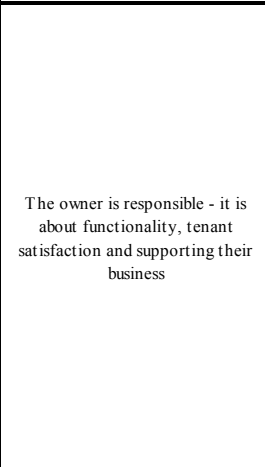 \\
\hline $\begin{array}{c}\text { Added value through life } \\
\text { cycle management }\end{array}$ & Yes, but it has to be controlled & 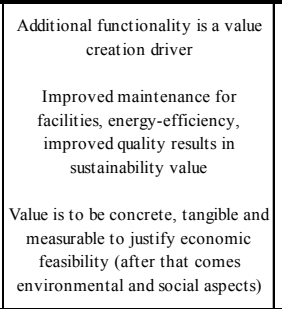 & 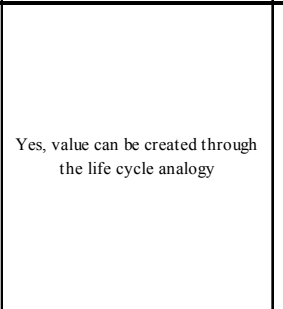 & 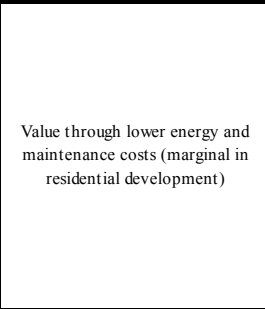 & 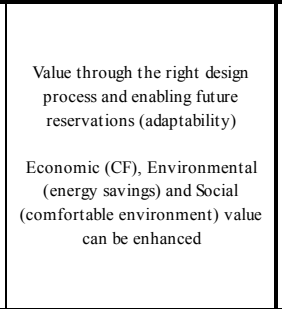 & 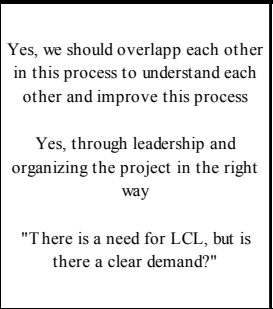 & 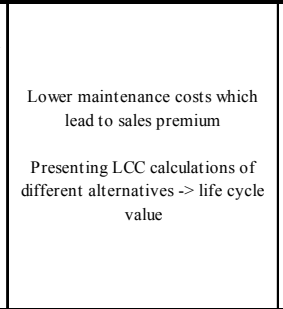 & 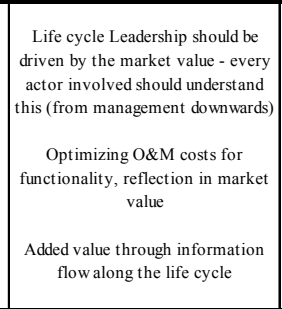 & \begin{tabular}{|l} 
Liff cycle value through pulic- \\
private-partnerships \\
O\&M savings and environmental \\
savings correlate \\
Yes, conomic value, but when is it \\
realized?
\end{tabular} & 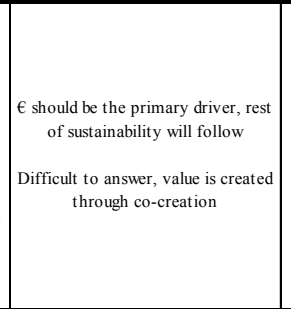 & 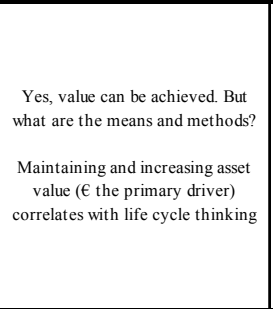 & 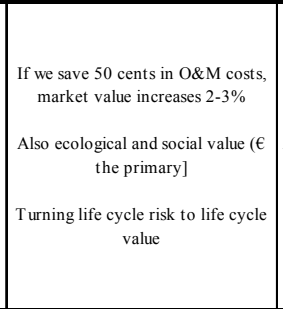 & 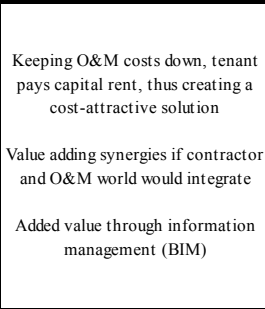 \\
\hline $\begin{array}{c}\text { Tools to enhance life cycle } \\
\text { management }\end{array}$ & $\begin{array}{c}\text { No suffficient tools today, need to } \\
\text { be neutral, comprehnsive and } \\
\text { diverse } \\
\text { LCC and LCA supports one another } \\
\text { Opend discussion for shared logic and } \\
\text { common interests is vital }\end{array}$ & 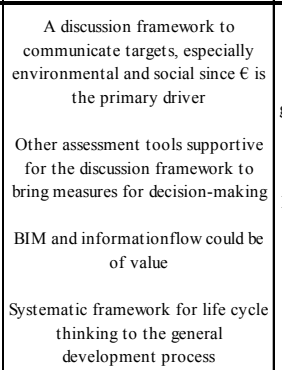 & 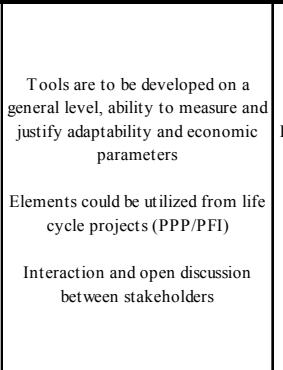 & 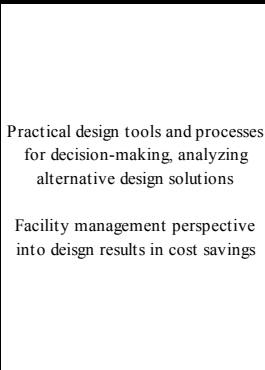 & 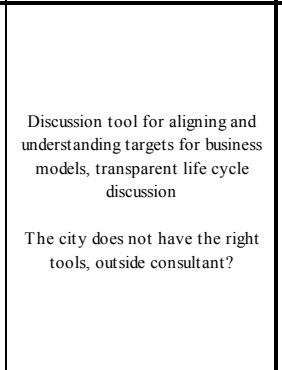 & 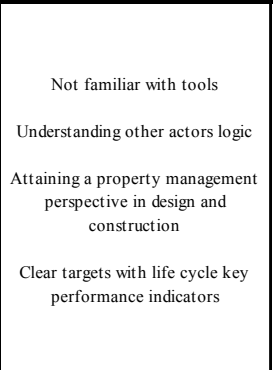 & 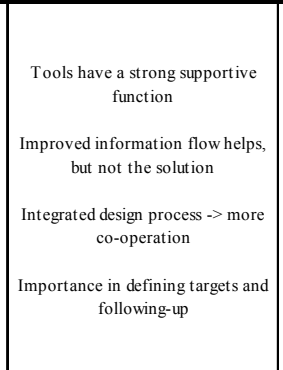 & \begin{tabular}{|c|} 
Integrated design solutions \\
Life cycle tools to justifify value \\
LCC represents major ( 10 ) costs \\
of propertics, thinking to be \\
included in design and construction
\end{tabular} & 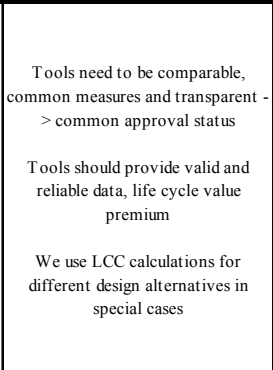 & 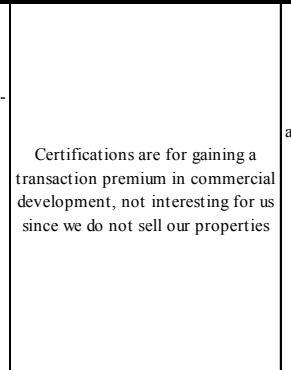 & 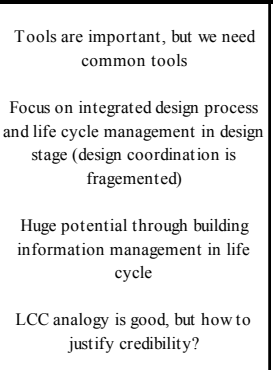 & 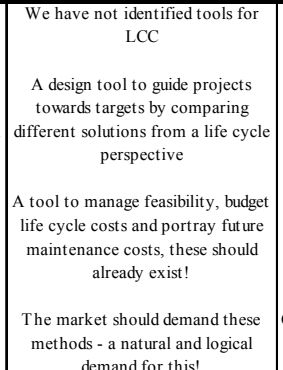 & 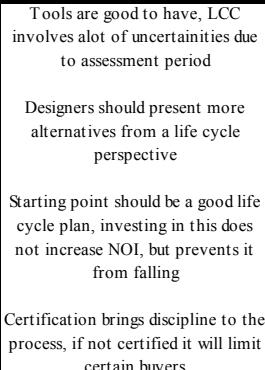 \\
\hline
\end{tabular}


Appendix 6-Identified Themes from Data Analysis

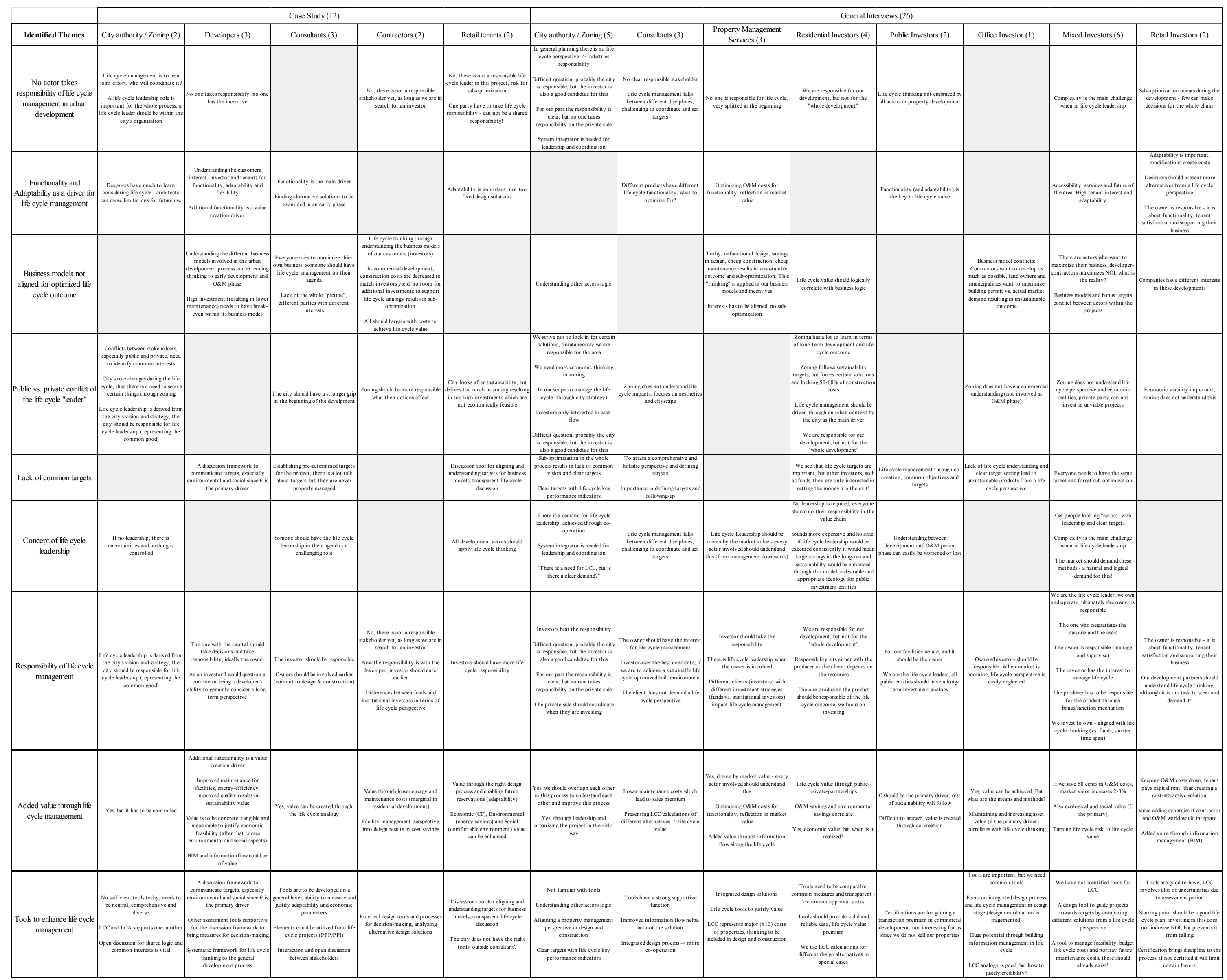




\section{References}

1. UN-HABITAT. City Planning will Determine Pace of Global Warming, Un-Habitat Chief Tells Second Committee as She Links Urban Poverty with Climate Change. 2007. Available online: http://www.un.org/News/Press/docs/2007/gaef3190.doc.htm (accessed on 23 June 2015).

2. United Nations Environment Programme (UNEP). Buildings and Climate Change Status, Challenges and Opportunities. 2007. Available online: http:/www.unep.org/sbci/pdfs/ BuildingsandClimateChange.pdf (accessed on 23 June 2015).

3. Gueye, M.K. Cities and Green Buildings, in the Transition to a Green Economy, a UNEP Brief. 2007. Available online: http://www.unep.org/urban_environment/PDFs/CitiesAndBuilding Factsheet_20091105.pdf (accessed on 23 June 2015).

4. Kresl, P.K. Urban Economy. Economies 2014, 2, 218-219.

5. Nauclér, T.; Enkvist, P. Pathways to a Low-Carbon Economy: Version 2 of the Global Greenhouse Gas Abatement Cost Curve; McKinsey \& Company: New York, NY, USA, 2009.

6. Bugliarello, G. Urban sustainability: Dilemmas, challenges and paradigms. Technol. Soc. 2006, 28, 19-26.

7. Godschalk, D.R. Land use planning challenges: Coping with conflicts in visions of sustainable development and livable communities. J. Am. Plan. Assoc. 2004, 70, 5-13.

8. UNEP/SETAC. Life Cycle Initiative Life cycle management: How business uses it to decrease footprint, create opportunities and make value chains more sustainable. Available online: http://www.unep.org/pdf/DTIE_PDFS/DTIx1208xPA-LifeCycleApproach-Howbusinessusesit.pdf (accessed on 9 September 2015).

9. Hunkeler, D.; Saur, K.; Rebitzer, G.; Finkbeiner, M.; Schmidth, W.-P.; Jensen, A.A.; Stranddorf, H.; Christiansen, K. Life-Cycle Management; SETAC Press: Pensacola, FL, USA, 2004; ISBN-10: 1880611775.

10. Baumann, H.; Tillman, A.-M. The Hitch Hiker's Guide to LCA: An Orientation in Life Cycle Assessment Methodology and Application; Studentlitteratur AB: Lund, Sweden, 2004; ISBN 9144023642.

11. Woodward, D.G. Life cycle costing-Theory, information acquisition and application. Int. J. Proj. Manag. 1997, 15, 335-344.

12. World Business Council for Sustainable Development (WBCSD). Energy Efficiency in Buildings, Facts \& Trends. October 2007. Available online: http://immobilierdurable.umapresence.com/ images/2128_uploads/WBCSD_EEB_final_rapport_n_.pdf (accessed on 23 June 2015).

13. Väyrynen, E. Towards an Innovative Process of Networked Development for a New Urban Area-Four Theoretical Approaches. Ph.D. Thesis, Aalto University School of Science and Technology, Espoo, Finland, June 2010.

14. Siponen, T.; Malvalehto, J.; Herrala, M.; Haapasalo, H. Kiinteistöjen Arvoketjuanalyysi. Research Reports in Department of Industrial Engineering and Management 1/2010. 2011. Available online: http://herkules.oulu.fi/isbn9789514293412/isbn9789514293412.pdf(accessed on 10 September 2015).

15. Brady, T.; Davies, A.; Gann, D. Can integrated solutions business models work in construction? Build. Res. Inf. 2005, 33, 571-579. 
16. Brady, T.; Davies, A.; Gann, D.M. Creating value by delivering integrated solutions. Int. J. Proj. Manag. 2005, 23, 360-365.

17. Winch, G. Zephyrs of creative destruction: understanding the management of innovation in construction. Build. Res. Inf. 1998, 26, 268-279.

18. Leiringer, R.; Green, S.D.; Raja, J.Z. Living up to the value agenda: the empirical realities of through-life value creation in construction. Constr. Manag. Econ. 2009, 27, 271-285.

19. Rajakallio, K.; Ristimäki, M.; Andelin, M.; Junnila, S. Business model renewal in context of integrated solutions delivery: A network perspective. IJSPM 2015, submitted.

20. Koskela, L.; Siriwardena, M.; Rooke, J. Through-Life Management of Built Facilities: Towards a Framework for Analysis. In Proceedings of IGLC16: 16th Annual Conference of the International Group for Lean Construction, Manchester, UK, 16-18 July 2008.

21. Lützkendorf, T.; Lorenz, D. Sustainable property investment: Valuing sustainable buildings through property performance assessment. Build. Res. Inf. 2005, 33, 212-234.

22. Kats, G.; Alevantis, L.; Berman, A.; Mills, E.; Perlman, J. The Costs and Financial Benefits of Green Buildings. 2003. Available online: http://www.usgbc.org/Docs/News/News477.pdf (accessed on 9 September 2015).

23. Koskelo, Taina. A Method for Strategic Technical Life Cycle Management of Real Estates. Ph.D. Thesis, Aalto University, Espoo, Finland, 2005.

24. Ciroth, A.; Finkbeier, M.; Hildenbrand, J.; Klöpffer, W.; Mazijn, B.; Prakash, S.; Sonnemann, G.; Traverso, M.; Ugaya, C.M.L.; Valdivia, S.; et al. Towards a Live Cycle Sustainability Assessment: Making Informed Choices on Products; United Nations Environment Programma: Paris, France, 2011.

25. Creswell, J.W. Research Design: Qualitative, Quantitative, and Mixed Methods Approaches, 4th ed.; Sage Publications: London, UK, 2014.

26. Moore, J.F. Predators and prey: a new ecology of competition. Harv. Bus. Rev. 1993, 71, 75-83.

27. Iansiti, M.; Levien, R. Strategy as ecology. Harv. Bus. Rev. 2004, 82, 68-81.

28. Thomas, L.; Autio, E. Modeling the Ecosystem: A Meta-Synthesis of Ecosystem and Related Literatures. In Proceedings DRUID Society 2012, Copenhagen, Denmark, 19-21 June 2012.

29. Kuronen, Matti. The role of partnerships in sustainable urban residential development. Ph.D. Thesis, Aalto University, Espoo, Finland, 2011.

30. Doak, J.; Karadimitriou, N. (Re)development, complexity and networks: a framework for research. Urban Stud. 2007, 44, 209-229.

31. Innes, J.E.; Booher, D.E. Consensus building and complex adaptive systems: A framework for evaluating collaborative planning. J. Am. Plan. Assoc. 1999, 65, 412-423.

32. Trevillion, E. Systems theory and the commercial development process-towards an understanding of complex behaviour and change. In Development and Developers: Perspectives on Property; Heriot-Watt University: Edinburgh, UK, 2002; pp. 181-203.

33. Remmen, A. Life Cycle Management: A Business Guide to Sustainability; UNEP/Earthprint: Nairobi, Kenya. 2007. Available online: http://www.unep.org/pdf/dtie/DTI0889PA.pdf (accessed on 10 September 2015).

34. Henriksson, P.J.G.; Guinée, J.B. Towards a practical application of life cycle sustainability analysis (LCSA): Perspectives on managing life cycles. In Proceedings of the 6th international conference on life cycle management, Gothenburg, Sweden, 25-28 August 2013. 
35. Kloepffer, W. Life cycle sustainability assessment of products. Int. J. Life Cycle Assess. 2008, 13, 89-95.

36. Finkbeiner, M.; Schau, E.M.; Lehmann, A.; Traverso, M. Towards life cycle sustainability assessment. Sustainability 2010, 2, 3309-3322.

37. Ristimäkki, M.; Säynäjoki, A.; Heinonen, J.; Junnila, S. Combining life cycle costing and life cycle assessment for an analysis of a new residential district energy system design. Energy 2013, 63, 168-179.

38. Stephan, A.; Crawford, R.H.; De Myttenaere, K. Multi-scale life cycle energy analysis of a low-density suburban neighbourhood in Melbourne, Australia. Build. Environ. 2013, 68, 35-49.

39. Lotteau, M.; Loubet, P.; Pousse, M.; Dufrasnes, E.; Sonnemann, G. Critical review of life cycle assessment (LCA) for the built environment at the neighborhood scale. Build. Environ. 2015, 93, $165-178$.

40. Jabareen, Y.R. Building a conceptual framework: philosophy, definitions, and procedure. Int. J. Qual. Methods 2009, 8, 49-62.

41. Jabareen, Y. A new conceptual framework for sustainable development. Environ. Dev. Sustain. 2008, 10, 179-192.

42. Yin, R.K. Applications of Case Study Research; Sage: New York, NY, USA, 2012.

43. Eppli, M.J.; Miles, M.; Berens, G.; Weiss, M. Real Estate Development: Principles and Process, Chapter 2; Urban Land Institute: Washington, D.C., USA, 2007.

44. KTI. Finnish Property Market Review Spring 2015. Available online: http://www.kti.fi/kti/ doc/markkinakatsaukset/Markkinakatsaus_K15_net.pdf (accessed on 22 June 2015). (In Finnish)

45. Ratcliffe, J. Scenario building: a suitable method for strategic property planning? Prop. Manag. 2000, 18, 127-144.

46. Hannus, J. Prosessijohtaminen: Ydinprosessien Uudistaminen Ja Yrityksen Suorituskyky, 4th ed.; HM\&V Research: Jyväskylä, Finland, 1994.

47. Smith, J.; Jackson, N. Strategic needs analysis: its role in brief development. Facilities 2000, 18, 502-512.

48. Amold, A.L.; Brown, R.K.; Rhodes, M.S.; Rabianski, J.S. Managing Corporate Real Estate; John Wiley \& Sons Inc: New York, NY, USA,1993.

49. Naess, P. Urban planning and sustainable development. Eur. Plan. Stud. 2001, 9, 503-524.

50. Klijn, E.; Koppenjan, J.F. Public management and policy networks: foundations of a network approach to governance. Public Manag. Int. J. Res. Theory 2000, 2, 135-158.

51. Organization for Economic Co-operation Development (OECD). OECD Principles on Water Governance. 2105. Available online: http://www.oecd.org/gov/regional-policy/OECD-Principleson-Water-Governance-brochure.pdf (accessed on 3 September 2015).

52. Camillus, J.C. Strategy as a Wicked Problem. 2008. Available online: http://www.induscommons.com/ files/102770262.pdf (accessed on 9 September 2015).

53. Davies, A. Moving base into high-value integrated solutions: a value stream approach. Ind. Corp. Chang. 2004, 13, 727-756.

54. Tuli, K.R.; Kohli, A.K.; Bharadwaj, S.G. Rethinking customer solutions: From product bundles to relational processes. J. Market. 2007, 71, 1-17. 
55. Krishnamurthy, C.; Johansson, J.; Schlissberg, H. Solutions selling: Is the pain worth the gain. McKinsey Mark. Solut. 2003, 1, 1-13.

56. Weber, E.P.; Khademian, A.M. Wicked problems, knowledge challenges, and collaborative capacity builders in network settings. Public Adm. Rev. 2008, 68, 334-349.

57. Saxon, R. Be Valuable: A Guide to Creating Value in the Built Environment; Constructing Excellence: London, UK, 2005.

(C) 2015 by the authors; licensee MDPI, Basel, Switzerland. This article is an open access article distributed under the terms and conditions of the Creative Commons Attribution license (http://creativecommons.org/licenses/by/4.0/). 